„Przekłady Literatur Słowiańskich”. T. 10, cz. 2

ISSN 2353-9763 (wersja elektroniczna)

DOI https://doi.org/10.31261/PLS.2020.10.02.08

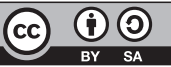

\title{
Granice nowego dramatu serbskiego - płynne i stale wytyczane na nowo Perspektywa lokalna i recepcja w Polsce
}

\author{
The Borders of the New Serbian Drama - \\ Fluid and Constantly Redefined: \\ The Local Perspective and Reception in Poland
}

\author{
Gabriela Abrasowicz \\ iD https://orcid.org/0000-0002-2977-4822 \\ UNIVERSITY OF SILESIA IN KATOWICE \\ abrasowicz.gabriela@gmail.com
}

Data zgłoszenia: 15.09 .2019 r. $\quad$ Data akceptacji: 25.02 .2020 r.

\begin{abstract}
Since the turn of the millennium, Serbian drama has been increasingly valued and recognized in the post-Yugoslav region and in Europe. In recent years, the process of globalization has become progressively stronger, with an improved infrastructure for promotion that has made possible the crossing of material and symbolic boundaries. This in turn has led to transformations in artistic expression, as well as increasing opportunities for mobility, co-productions, and translations. The status of the drama has been somewhat problematic because of its situation between literature and theatre. Its heterogeneous nature has required the development of an appropriate method of presentation. The performative/stage reading has emerged as a compelling answer.
\end{abstract}

KEYWORDS | Serbian drama and theatre, translation of the dramatic text, performative/stage readings, promotion system, Serbian drama in Poland

* Praca powstała w ramach projektu badawczego nr 2017/24/C/HS2/00436, finansowanego ze środków Narodowego Centrum Nauki. 
Zagadnienie kondycji i rozwoju dramatopisarstwa serbskiego w pierwszych latach nowego tysiąclecia zostało w Polsce opisane w nielicznych jak dotąd, ale interesujących opracowaniach. Na uwagę zasługuje wstęp ${ }^{1}$ autorstwa Agnieszki Cielesty i Dominiki Zwierzchowskiej do antologii Serbska ruletka. Dramat serbski po 1995 roku. Wybór tekstów, a także praca licencjacka Anny Sokulskiej, której fragmenty zostały opublikowane w artykule Dramat kobiecy, kobieta $w$ dramacie. Wokół dramaturgii Mai Pelević ${ }^{2}$ Specyfikę kształtowania się wariantu kobiecego dramatopisarstwa scharakteryzowano w komparatystycznej rozprawie doktorskiej wydanej pod tytułem Dramat ciała, ciało $w$ dramacie. Twórczość serbskich i chorwackich dramatopisarek w latach 1990-2010 ${ }^{3}$. Polski odbiór produkcji dramatopisarskiej powstającej w Serbii przedstawiła natomiast Magdalena Bogusławska w analizie Kulturowe aspekty recepcji serbskiego dramatu $w$ polskim teatrze współczesnym ${ }^{4}$. Dokonując swoistej aktualizacji i rozbudowując przegląd o rozważania dotyczące najnowszych przekształceń oraz faktycznego i symbolicznego zasięgu serbskiego dramatu, skoncentruję się zatem na informacjach nieuwzględnionych w pracach wspomnianych badaczek, choć nie sposób w pewnych momentach uniknąć niezbędnych powtórzeń.

\section{Status nowego rodzimego dramatopisarstwa w Serbii - publikacje i realizacje (około)sceniczne}

Nie ulega wątpliwości, że na przełomie tysiącleci dramat serbski jako propozycja do opracowania scenicznego (bo taka jest zazwyczaj intencja twórców) stał się najbardziej cenionym oraz rozpoznawalnym intelektualnym towarem eksportowym z tych terenów w mikro- i makroskali. Jest to nośne i atrakcyjne tworzywo artystyczne wykorzystywane z powodzeniem przez autorów, którzy

1 A. Cielesta, D. Zwierzchowska, 2011: Dramat serbski po 1995 roku. W: A. Cielesta, L. Małczak, D. Zwierzchowska, red.: Serbska ruletka. Dramat serbski po 1995 roku. T. 1. Katowice, Wydawnictwo Uniwersytetu Śląskiego, s. 9-42.

2 A. Sokulska, 2014: Dramat kobiecy, kobieta w dramacie. Wokół dramaturgii Mai Pelević. „Studenckie Zeszyty Naukowe Instytutu Filologii Słowiańskiej UJ”, numer specjalny, s. $5-51$.

3 G. Abrasowicz, 2016: Dramat ciała, ciało w dramacie. Twórczość serbskich i chorwackich dramatopisarek $w$ latach 1990-2010. Wrocław, Atut.

4 M. Bogusławska, 2017: Kulturowe aspekty recepcji serbskiego dramatu w polskim teatrze współczesnym. „Studia Litteraria Universitatis Iagellonicae Cracoviensis”, nr 12, z. 1, s. $1-13$. 
utracili swoje ideologiczne, narodowe, polityczne, moralne, a nawet metafizyczne podstawy życia oraz doświadczyli „rozrzedzenia tożsamości narodowej”. Do refleksji skłania krytyczna uwaga Nebojšy Romčevicia, która zamyka tekst włączony do wstępu antologii Serbska ruletka. Dramatopisarz twierdzi mianowicie, że w kwestii serbskiej twórczości

wciąż nie doszło do estetycznego i merytorycznego zwrotu, zarówno w odniesieniu do tekstu, jak i reżyserii. Spotkanie pokoleń nie skończyło się konfliktem, lecz kompromisem partiokratycznych kierownictw teatru. Teatr utracił swój dysydencki status, wybrał bezbarwną neutralność i stał się kolejną pozycją w budżecie. Serbski teatr znajduje się w sytuacji wyczekiwania zmiany; czy ona nastąpi (czy jest możliwa), w coraz mniejszym stopniu zależy od teatru'

Spojrzenie $\mathrm{z}$ dystansu nie pozwala $\mathrm{w}$ pełni zgodzić się $\mathrm{z}$ tą pesymistyczną diagnozą. Od ponad dekady serbscy dramatopisarze i dramatopisarki ${ }^{7}$, powołując do życia nowe teksty, rozwijali efekty przemian znacznie wcześniejszych. Reorganizacja pewnych wzorców i dyskursów pozwala uznać ich paradygmat twórczy tylko w pewnej mierze za kontynuowanie strategii poprzedników, a wśród przykładów nowej artykulacji artystycznej jest wiele utworów, do których nie przystają określenia: „wtórne”, „jałowe” lub „koniunkturalne”. Tak jak zauważył serbski reżyser Miloš Lazin, szukając wspólnego mianownika wcześniejszych tekstów (napisanych w pierwszych latach XX wieku), również te najnowsze kształtują się w obrębie trzech łączliwych i zazębiających się trybów: postdramatycznego (odrzucającego naśladownictwo), fantasmagorycznego i pozornie realistycznego (skoncentrowanego na zapożyczeniach i kompilacjach) ${ }^{8}$, jednak poprzez inne rozłożenie akcentów zyskują one nowy wymiar. Po pozornym zwolnieniu z odpowiedzialności oraz postpolitycznym ${ }^{9}$ odwrocie od wielkich

5 N. Romčević, 2011: Teatr w Serbii w latach 1990-2010. L. Małczak, tłum. W: Serbska ruletka..., s. $43-44$.

6 Ibidem, s. 48-49.

7 Godne uwagi są dzieła autorów i autorek takich jak: Staša Bajac, Iva Brdar, Olga Dimitrijević, Dimitrije Kokanov, Milan Marković, Maja Pelević, Ognjen Obradović.

8 M. Lazin, 2007: Nova drama - nova gluma? W: S. Anđelković, B. Senker, red.: Govor drame. Govor glume. Zagreb, Disput, s. 112.

9 Określenie Any Vujanović. A. Vujanović, 2010: Nova - „postpolitička” - drama. W: M. Šuvaković, red.: Istorija umetnosti u Srbiji XX vek. Beograd, Orion Art, s. 771778. Jak wyjaśnia Vujanović, podstawowym budulcem dramatu postpolitycznego nie były momenty przesądzające o historii i aktualnej kondycji Serbów, choć utwory napisane przez wówczas młodych autorów i autorki: Uglješę Šajtinaca, Milana Markovicia, Filipa Vujoševicia, Maję Pelević, Minję Bogavac, nie odcinały się od tych kwestii (pojawiających się głównie jako fragmenty obrazów medialnych). Akcent w postpolitycznych tekstach dramatycznych był raczej przesunięty na opis intymnych problemów jednostki w posthistorycznym społeczeństwie w fazie przejściowej. 
dramatów społecznych o konfliktach, przesileniach, kryzysach, rewolucjach i od entuzjastycznej wiary w „lepszy świat” (co komentował właśnie Romčević) nastąpiła bardzo szybko ultrapolityczna wręcz reorientacja artystyczna. Obecnie autorzy tworzą swego rodzaju eksperymenty, podczas których obcowanie z dramatem - inaczej skrojonym i wymykającym się powszechnym przyzwyczajeniom - staje się wyzwaniem dla widza, gdyż wymaga od niego aktywnego udziału, prowokuje do współkreacji zdarzenia, a tym samym podaje w wątpliwość makro- i mikropolityczne konstrukty organizujące codzienność i konfigurujące tożsamość ${ }^{10}$. Ta zaangażowana twórczość podszyta jest nowoczesnymi teoriami, które rezonują z otaczającą rzeczywistością (na poziomie ponadlokalnym), oznacza odważne próby rozliczenia się z kulturowym dziedzictwem kraju. Współczesny dramat powstaje w Serbii jako dokument społecznych przemian, zwierciadło politycznych poglądów i filozoficznych przekonań, ma charakter demaskatorsko-interwencyjny. Dzięki radykalnej odnowie jakościowej serbski dramat XXI wieku stał się formą bardziej adekwatną do ekspresji artystycznej powiązanej z zaangażowaniem społecznym, które nie sprowadza się do podsuwania widzom gotowych rozwiązań na uporządkowanie świata, lecz polega na zmuszaniu ich do podjęcia intelektualnego wysiłku w celu lepszego zrozumienia przedstawianych problemów ${ }^{11}$.

W ostatnich latach twórczość współczesnych dramatopisarzy i dramatopisarek aktywnych w Serbii zdecydowanie rozbudziła zainteresowanie w lokalnym, regionalnym, a także europejskim środowisku teatralnym. Wielu twórców wspomina jednak początek tysiąclecia jako okres dość problematyczny dla ekspansji dramatu. Warta podkreślenia w kontekście historycznym jest analiza przeprowadzona przez Anę Vujanović ${ }^{12}$. W pracy z 2004 roku badaczka zwróciła uwagę na fakt, że w nowym milenium ujawniła się w Serbii nowa generacja bardzo produktywnych dramatopisarzy i dramatopisarek, którzy dość szybko znaleźli swoje miejsce w najbliższej przestrzeni artystycznej. Nie była to jednak pełna obecność. Zabrakło wówczas pewnych systemowych rozwiązań i infrastruktury organizacyjnej, które pomogłyby im opublikować dany tekst i przenieść go na poziom spektaklu. Propozycje debiutantów, pozbawione należytej ekspozycji

10 D. Đurić, 2013: Politika i teatar: „Zoran Đinđič" Olivera Frljića i „Oni žive” Milana Markovića i Maje Pelević. „Poznańskie Studia Slawistyczne”, nr 5, s. 91.

11 R. Kielawski, A. Samanipour, 2015: Różne wymiary udomowienia w tłumaczeniu dramatu - „Love and Information Caryl Churchill” w przekładzie Pawła Demirskiego. W: A. Filipek, M. Osiecka, M. Gwóźdź, K. Małajowicz, red.: Wkład w przekład 3. Kraków, Korporacja Ha!art, s. 167.

12 A. Vujanović, 2004: Drama bez scene: hrapave konceptualizacije dramske produkcije novih autora u Srbiji. „Scena”, nr 4. Dostępne w Internecie: http://www.pozorje.org. rs/stari-sajt/scena/scena404/19.htm [dostęp: 13.09.2019]. 
i wartościowania, zostały według Vujanović skazane na funkcjonowanie w kategoriach „dramatów bez sceny”.

Uaktywnienie się mniej więcej w tym samym momencie licznej grupy stawiających pierwsze kroki w branży dramatopisarzy i dramatopisarek było wówczas zupełną nowością dla serbskiej sceny teatralnej. Wcześniej charakteryzowała się ona przedłużonymi okresami reprodukcji istniejącego już dziedzictwa dramatycznego przeplatanymi krótszymi epizodami pojawiania się pojedynczych autorów lub autorek, którzy zdobywali powszechne uznanie. W najnowszej historii było podobnie. Lata 90. minionego wieku zdominowane były przez dramaty Biljany Srbljanović, a następnie Mileny Marković, za sprawą których twórczynie nasyciły świat teatralny świeżym podejściem do problemów wymagających od dawna rozwiązania. Po tym, zgodnie z oczekiwaniami dotyczącymi pewnej regularności, nastała faza odtwarzania, w której brakowało nowych odkryć. Począwszy od 2000 i 2001 roku, sytuacja zaczęła się zmieniać, ponieważ do głosu doszło wówczas kilkunastu młodych autorów tekstów dramatycznych jeszcze studentów lub świeżo upieczonych absolwentów Wydziału Sztuk Dramatycznych w Belgradzie (Fakultet dramskih umetnosti u Beogradu - FDU).

Dramaty wychodzące spod pióra przedstawicieli i przedstawicielek młodego pokolenia nie były wówczas wystawiane w państwowych i miejskich teatrach repertuarowych, a z pewnością nie na dużych scenach. Teksty te jednak odnalazły alternatywne drogi do materializacji scenicznej i publiczność względnie szybko mogła je w tej wersji poznać. Realizacje miały miejsce głównie w niezależnej instytucji, jaką jest belgradzki Teatr Bitef (Bitef teatar). W pamięć widzów wpisały się North Force i Czerwona (Crvena) Mileny Minji Bogavac w latach 2003-2004. Inną opcją była platforma teatralna Studenckiego Centrum Kultury w Belgradzie (Studentski kulturni centar u Beogradu), gdzie w 2004 roku wystawiono trylogię dramatyczną w ramach omnibusu Belgradzkie opowieści (Beogradske priče) autorstwa Mai Pelević i Ljubinki Stojanović: ESCape, Belgrad-Londyn (Beograd-London) i Złota wędka (Zlatna udica). Na małych scenach znanych teatrów w ramach cykli tematycznych pojawiały się okazjonalnie spektakle oparte na pomysłach młodych autorów, np. w Belgradzkim Teatrze Dramatycznym (Beogradsko dramsko pozorište), teatrze Atelje 212, Teatrze Narodowym w Belgradzie (Narodno pozorište u Beogradu), salonie kultury Plato Plus, Teatrze Narodowym w Suboticy (Narodno pozorište u Subotici / Szabadkai Népszínház). Wariantem przybliżania odbiorcom tej twórczości były także słuchowiska emitowane na antenie Radia Belgrad (Radio Beograd), np. sztuki Mileny Minji Bogavac Operacja emocjonalna werbalizacja (Operacija emocionalna verbalizacija) w 2004 roku i Wszyscy inni (Svi drugi) w 2003 roku.

Czytania performatywne (sceniczne) były wtedy częstą praktyką, która miała pomóc autorom i autorkom w przedostaniu się do mainstreamu. Przestrzenią 
dla tego rodzaju przedsięwzięć była wówczas przede wszystkim V scena Teatru Narodowego w Belgradzie, na której w ramach projektu rozwoju tekstu dramatycznego NovA DramA (NADA ${ }^{13}$ ) publiczność miała sposobność poznać utwory Luz (Ler) Mai Pelević i Drogi tato (Dragi tata) Mileny Minji Bogavac, a podczas festiwalu Niewinność (Nevinost) w Nowym Sadzie czytany był inny dramat Pelević - Dzieci w formalinie (Deca u formalinu, 2003). Później czytania performatywne zostały wprowadzone między innymi do programu forum Assitej Srbija, festiwalu Teatralna Wiosna (Pozorišno proleće, Šabac), festiwalu Sterijino pozorje (Nowy Sad), a w kwietniu 2019 roku w Teatrze Narodowym w Belgradzie uruchomiono Pracownię (Radionica) z odrębną sceną, na której "Czytanki” mają stać się stałym elementem.

Warto wspomnieć, że teksty te ożywały w teatrach i programach radiowych, ale nie w reżyserii uznanych już wtedy, doświadczonych artystów, lecz najczęściej rówieśników autorów tekstów, takich jak Jelena Bogavac, Ana Tomović, Slađana Kilibarda, Boris Liješević, Iva Milošević (dziś czołowych reżyserów). Reguła ta odnosiła się także do pozostałych członków zespołu realizacyjnego za sporadyczne produkcje, które doszły do skutku przy minimalnym nakładzie kosztów, odpowiedzialny był zazwyczaj zespół młodych (początkujących, ale ambitnych i autonomicznych) twórców.

„Dramatowi bez sceny” nie zagwarantowano stałego miejsca w strefie teatru i systematycznego wystawiania, zatem pozostawał on niejako zablokowany na poziomie wyłącznie lektury. Twórczości tej nie wspierała dominująca platforma dyskursywna, dlatego była to sztuka stale poszukująca alternatywnej, własnej przestrzeni, w której mogłaby urzeczywistniać się wbrew obowiązującym prawom. Ignorowanie dokonań młodych twórców, a w rezultacie niemożność ich przebicia się do profesjonalnych scen, pomagało utrzymać (zbyt długo) status quo dość zachowawczej produkcji teatralnej w Serbii. Zasadna w odniesieniu do tej sytuacji jest uwaga Pawła Demirskiego, który w swoim manifeście krytycznie skomentował podobną kondycję dramatopisarstwa w Polsce ${ }^{14}$ i wskazał wyjście z analogicznej pułapki kanoniczności: przemyślenie zmiany perspektywy $\mathrm{z}$ teatru reżysersko-centrycznego w kierunku modelu teatru dramatopisarza. W przypadku serbskiej produkcji po fazie marginalizacji odnotować można właśnie zwrot w stronę nowego tekstu i jego ponowną nobilitację.

Dzisiaj przenikanie młodych autorów do teatrów instytucjonalnych jest zdecydowanie łatwiejsze. Milena Minja Bogavac, odwołując się do własnych

13 Projekt został zainicjowany w 2002 roku pod egidą Teatru Narodowego w Belgradzie (Narodno pozorište u Beogradu), a jego celem było zachęcanie współczesnych dramatopisarzy do pisania sztuk teatralnych, a także promowanie ich twórczości i umożliwianie im nawiązania współpracy z reżyserami.

14 P. Demirski, 2015: Teatr dramatopisarzy. „Polish Theatre Journal”, nr 1, s. 3. 
doświadczeń oraz obserwacji aktualnych prawidłowości, konkluduje, że „młodzi twórcy rzadziej działają na marginesie głównego nurtu, nie organizują i nie umacniają już przestrzeni alternatywnej, bo widocznie nie mają takiej potrzeby"15. Generacja Bogavac przezwyciężyła wprawdzie pierwsze trudności, ale to najmłodsi autorzy, tacy jak Tijana Grumić, Filip Grujić i Dunja Matić, przerwali wcześniejszą blokadę i skutecznie minimalizują opór względem nowego dramatopisarstwa. Chociaż pierwsze produkcje na podstawie tekstów Grujicia i Matić powstały na niezależnych scenach, to jednak w porównaniu ze spektaklami sprzed dekady charakteryzowały się one znacznie wyższym poziomem realizacji oraz sprawniejszym systemem promocji. Młodzi autorzy i autorki docierają do publiczności w nieco innej kolejności, mają bowiem więcej możliwości, aby zaistnieć w mniejszych miastach, a dopiero później ich dążeniem są belgradzkie premiery. Istotny jest fakt, że w strukturach teatrów również doszło do pewnej zmiany pokoleniowej. Osoby decyzyjne, świadome wartości nowego dramatopisarstwa i przychylne autorom (często swoim rówieśnikom, jak Tanja Šljivar - dyrektorka ds. dramatu w Teatrze Narodowym w Belgradzie lub Milena Minja Bogavac - dyrektorka Teatru w Šabacu), wprowadzają sztuki do repertuarów lub specjalnych programów realizowanych na małych scenach, poszerzając tym samym teatralny kanon.

Jak wskazuje Marina Milivojević Mađarev w swoim raporcie Co się drukuje, a co wystawia ze wspótczesnego serbskiego dramatopisarstwa (2003-2015) [Šta se štampa, a šta izvodi od savremene srpske dramske književnosti (2003-2015) ${ }^{16}$ ], pod koniec pierwszego dziesięciolecia XXI wieku zaobserwować można delikatny spadek natężenia publikacji książkowych zawierających teksty dramatyczne. Teatrolożka tłumaczy to ówczesnymi aspiracjami dramatopisarzy, aby ich twórczość przede wszystkim ujrzała światła sceny. Do wydania swoich tekstów dążyli tylko wtedy, gdy spektakl na podstawie ich utworu spotykał się z pozytywnym oddźwiękiem lub gdy sam pisarz odnosił wrażenie, że wydrukowanie książki jest jedynym sposobem, aby jego dzieło weszło w obieg publiczny.

Najbardziej produktywnym wydawcą było w tym okresie Stowarzyszenie Dramatopisarzy Serbii (Udruženje dramskih pisaca Srbije - UDPS), które w ciągu dwóch lat opublikowało w zbiorach Współczesny dramat serbski (Savremena srpska drama) ponad 40 tytułów. Poza tym zauważalna jest pewna zależność: znane domy wydawnicze opublikowały utwory (często zbiory dramatów) znanych autorów, a największa liczba pojedynczych tekstów dramatycznych mogła dotrzeć do czytelników dzięki małym wydawnictwom. W druku udostępniono

15 Rozmowa G. Abrasowicz z M.M. Bogavac, komunikator internetowy, 22.09.2019.

16 M. Milivojević Mađarev, 2015: Šta se štampa, a šta izvodi od savremene srpske dramske književnosti (2003-2015). „Scena”, nr 4, s. 126-135. 
teksty Biljany Srbljanović, Nebojšy Romčevicia, Milana Markovicia, Uglješy Te osobne wydania były na ogół próbą podsumowania dorobku dramatopisarzy wielkiego formatu, a nie sposobem prezentowania nowych utworów.

Teatry również drukowały teksty dramatyczne, na podstawie których powstawały wybrane spektakle. Jugosłowiański Teatr Dramatyczny (Jugoslovensko dramsko pozorište, JDP) opublikował sztukę Banat Uglješy Šajtinaca i dwa dramaty Biljany Srbljanović - Barbelo, o psach i dzieciach (Barbelo, o psima i deci) oraz Szarańcza (Skakavci). Serbski Teatr Narodowy (Srpsko narodno pozorište - SNP) wydał utwór Ja albo ktoś inny (Ja ili neko drugi) Mai Pelević, a Budva Grad teatar upowszechnił tekst Don Krsto Vidy Ognjenović. Po roku 2010 działalność wydawnicza teatrów jest epizodyczna, ale zasługuje na uwagę. Przede wszystkim należy podkreślić przedsięwzięcie belgradzkiego Teatru Dadov. Dwukrotnie, w 2009 i 2011 roku, ukazały się dzięki niemu dwa zbiory zawierające dramaty i dramatyzacje autorstwa Mileny Minji Bogavac, Mai Pelević, Olgi Dimitrijević, Ljubinki Stojanović, Tamary Jovanović, Branislavy Ilić i Jeleny Đorđević. Trudno jest dotrzeć do tego ekskluzywnego wydania, jeśli potencjalny czytelnik nie zgłosi się bezpośrednio do siedziby Teatru Dadov albo Biblioteki Narodowej Serbii. Dość niezwykłym posunięciem okazała się natomiast akcja Jugosłowiańskiego Teatru Dramatycznego w 2011 roku, kiedy to we współpracy z dziennikiem „Danas” opublikowano dramat Śmierć to nie rower, nie ukradna ci go (Nije smrt biciklo da ti ga ukradu) Biljany Srbljanović, na podstawie którego powstał spektakl w JDP. Każdy kupujący gazetę w dniu premiery (17.06.2011) otrzymał podarunek w postaci książki. Ten niezwykły przykład współpracy między dwiema instytucjami to niestety wyjątek, a nie reguła.

Marina Milivojević Mađarev konstatuje, że w ostatnich latach na rynku wydawniczym pojawiały się dramaty albo już uznanych, albo prawie nieznanych autorów. Gdy mowa o dramatopisarzach i dramatopisarkach takich jak Dušan Kovačević, Vida Ognjenović i Milena Marković, to w druku ukazały się sztuki, które zostały już zaprezentowane na deskach teatrów, a jeśli chodzi o początkujących autorów, ich propozycje, choć opublikowane, prawdopodobnie nigdy nie przekształcą się w spektakle. Te dramaty, przez brak ukierunkowania na konkretny repertuar i oczekiwania publiczności, są - zdaniem badaczki równoległym (i dość odległym) światem względem życia teatralnego.

W latach 2013-2015 dramatopisarze zajęli się biografiami sławnych pisarzy i artystów, przede wszystkim Jovana Sterii Popovicia (dramaty Patriota Rodoljubac Milovana Vitezovicia, Mi-Sterija Petara Grujičicia, Latająca trupa - Leteća trupa Danicy Nikolić Nikolić) i Branislava Nušicia (Urodziny pana Nušića - Rođendan gospodina Nušića Dušana Kovačevicia, Trzy klasy i pani Nušić - Tri klase i gospođa Nušić Vladimira Đurđevicia). Powstał wówczas także 
spektakl Kainowe piętno (Kainov ožiljak ${ }^{17}$ ), którego bohaterem jest noblista Ivo Andrić. W 2014 roku szczególną uwagę poświęcono setnej rocznicy wybuchu I wojny światowej oraz postaci Gavrila Principa. Takie projekty zrealizowały autorki: Biljana Srbljanović (Za mały dla mnie ten grób - Mali mi je ovaj grob), Milena Marković (Smokobójcy - Zmajeubice) i Danica Nikolić Nikolić (Drita), a także dramatopisarze: Nebojša Bradić (Princip Super-Star), Nenad Prokić (Palec spust nabój pistolet - Prst obarač metak pištolj) i Spasoje Ž. Milovanović (Proch i popiót - Prah i pepeo). Nagrodę za tekst dramatyczny w ramach konkursu Sterijino pozorje otrzymały w 2014 roku Biljana Srbljanović, a rok później Milena Marković. Poza tym nurtem odbiorców zaintrygowała ekspresja artystyczna dramaturgów i dramaturżek związanych wcześniej z projektem NADA: Filipa Vujoševicia, Mai Pelević, Fedora Šilego i Mileny Minji Bogavac, którzy skoncentrowali się na opracowaniu tematu tranzycji ${ }^{18} \mathrm{i}$ jej przejawów.

Na pierwszy rzut oka serbskie sztuki po 2010 roku są wystawiane, autorzy tekstów i reżyserzy otrzymują nagrody, jednak śledząc teatralną egzystencję niektórych tytułów, można dojść do niepokojących wniosków. Praktycznie prawie $90 \%$ sztuk nie udaje się przetrwać po premierze i są dość szybko ściągane $\mathrm{z}$ afisza. Symptomatyczny jest także fakt, że utwory współczesnych cenionych autorów i autorek, takich jak Biljana Srbljanović i Milena Marković, bardzo rzadko są ponownie opracowywane scenicznie $w$ innych krajowych teatrach. Chociaż dyrektorzy teatrów zapewniają, że zależy im na umacnianiu pozycji serbskiego dramatopisarstwa, to jednak chętniej podejmują się produkcji, bazując na tekstach klasyków.

Okazją dla młodych autorów, aby wypłynąć na szerokie wody, bywa od jakiegoś czasu tradycja konkursowa, ponieważ nagroda pieniężna w przypadku wygranej idzie często $\mathrm{w}$ parze z publikacją, a nawet realizacją sceniczną. W sytuacji, którą opisała w przywołanym tu tekście Ana Vujanović, artyści nie mieli takich możliwości.

Istotną rolę $\mathrm{w}$ procesie umacniania pozycji autorów odegrała dwutomowa antologia współczesnego dramatu serbskiego pod redakcją Svetislava Jovanova i Vesny Jezerkić, w której pojawiły się nazwiska twórców pomijanych dotąd w tego typu podsumowaniach ${ }^{19}$. Po tej znanej także wśród polskich slawistów

17 Spektakl na podstawie książki Vladimira Kecmanovicia i Dejana Stojiljkovicia. Autorem dramatyzacji jest Spasoje Ž. Milovanović.

18 Termin „tranzycja” oznacza przejście od systemu niedemokratycznego do systemu liberalnej demokracji i według Witolda Morawskiego nie powinien być traktowany jako synonim „transformacji”, por. W. Morawski, 1998: Zmiana instytucjonalna. Społeczeństwo, gospodarka, polityka. Warszawa, Wydawnictwo Naukowe PWN, s. 35-36.

19 V. Jezerkić, S. Jovanov, red., 2006: Predsmrtna mladost: antologija najnovije srpske drame (1995-2005). I deo. Novi Sad, Sterijino pozorje; V. Jezerkić, S. Jovanov, red., 
publikacji przybliżającej produkcję z przełomu tysiącleci pojawiły się kolejne zbiory dramatów, których redaktorzy i wydawcy kierowali się już inną zasadą doboru tekstów. Główne kryterium promocji młodych autorów było silnie sprzężone z pewnego rodzaju współzawodnictwem. Książki Radnici umiru pevajući. Drame ${ }^{20}$, Prst. Zbirka savremene drame $2^{21}$, które powstały z inicjatywy belgradzkiej Fundacji Hartefakt, zawierają sztuki nagrodzone i wyróżnione w regionalnym, organizowanym przez tę fundację, konkursie na najlepszy współczesny dramat zaangażowany pisany w języku serbskim, chorwackim, bośniackim albo czarnogórskim. Zaznaczę, że nagrodą w tym konkursie jest nie tylko publikacja tekstu, lecz także wsparcie laureata (a częściej laureatki ${ }^{22}$ ) w realizacji spektaklu lub czytania performatywnego (najczęściej przy współpracy z Teatrem Bitef). Pracownicy Instytucji Kultury Parostatek (UK Parobrod) i Domu Młodzieży Belgradu (Dom omladine Beograda) organizowali cykle czytań scenicznych na podstawie tekstów młodych autorów i autorek, którzy dopiero walczyli o ugruntowaną pozycję lub widoczność w ogóle. Punktem zwrotnym w tej działalności był Festiwal Współczesnej Dramaturgii Serbskiej

2007: Istorija i iluzija: antologija najnovije srpske drame (1995-2005). II deo. Novi Sad, Sterijino pozorje. Sztandarowym zbiorem prezentującym dorobek serbskich dramatopisarzy, powstałym jeszcze w czasach Jugosławii (w 1977 roku), jest Antologia wspótczesnego dramatu serbskiego pod redakcją Slobodana Selenicia (Antologija savremene srpske drame). Wybitny dramatopisarz uwzględnił w swym wyborze utwory Đorđa Lebovicia i Aleksandra Obrenovicia - Himmelkommando (Nebeski odred), Miodraga Pavlovicia - Przed tym (Pre toga), Velimira Lukicia - Dlugie życie króla Oswalda (Dugi život kralja Osvalda), Borislava Mihajlovicia Mihiza - Banović Strahinja, Jovana Hristicia - Savonarola i jego przyjaciele (Savonarola i njegovi prijatelji), Aleksandra Popovicia - Pończocha ze stu oczek (Čarapa od sto petlji), Borislava Pekicia - Generałowie, czyli braterstwo broni (Generali ili srodstvo po oružju) i Dušana Kovačevicia - Maratończycy biegna honorowa rundę (Maratonci trče počasni krug). $\mathrm{Na}$ uwagę zasługują także nowsze, ukierunkowane publikacje: Antologia serbskiego dramatu dla dzieci (Antologija srpske drame za decu, 2001) przygotowana przez Branislava Kravljanaca oraz dwutomowa propozycja Miroslava Jokicia i Zvonimira Kosticia z 2004 roku: Antologia serbskiego dramatu radiowego 1939-2004 (Antologija srpske radio-drame 1939-2004) wydana we współpracy z Programem Dramatycznym Radia Belgrad.

20 M. Stefanović, T. Kaliterna, red., 2011: Radnici umiru pevajući. Drame. Beograd, Hartefakt fond.

21 V. Bošković, red., 2012: Prst. Zbirka savremene drame 2. Beograd, Hartefakt fond.

22 Na przestrzeni lat za najlepsze dramaty uznano: Robotnicy umieraja z pieśniq na ustach (Radnici umiru pevajući) Olgi Dimitrijević (2010), Palec (Prst) Doruntiny Bashy (2011), Šta je ona kriva nije ništa ona kriva (Czemu ona winna, ona niczemu nie jest winna) Vesny Perić (2012), Obudź mnie, gdy to się skończy (Probudi me kad završi) Mirzy Skenderagicia (2016), Ten będzie inny (Ovaj će biti drugačiji) Stašy Bajac (2017), Pelargonie moga przetrwać wszystko (Muškatle mogu preživeti sve) Ivy Brdar (2018), Ostrzał (Granatiranje) Dino Pešuta (2019). 
„Perły z dyrektorskich szuflad” (Festival savremene srpske dramaturgije „Biseri iz upravničkih fioka"), którego program obejmował, oprócz czytań, spektakle oraz dyskusje z teatrologami i twórcami. Organizatorzy uznali, że po tych wydarzeniach artystycznych powinien pozostać jakiś ślad, i zdecydowali się wydać zestawienie najciekawszych, ich zdaniem, tekstów. Biseri iz upravničkih fioka ${ }^{23}$ to okazały tom zawierający aż 19 utworów rozstrzygających w karierze między innymi Filipa Vujoševicia, Petara Mihajlovicia, Tanji Šljivar, Branislavy Ilić, Mai Pelević i Stašy Bajac.

Nie sposób w tym wykazie pominąć prestiżowego festiwalu Sterijino pozorje cieszącego się długą tradycją, na którą składa się pielęgnowanie i propagowanie serbskiego dramatopisarstwa. W ramach tego wydarzenia przyznawane są corocznie nagrody za współczesny tekst dramatyczny. W latach 2012-2019 zdobyli ją Olga Dimitrijević, Fedor Šili, Biljana Srbljanović, Milena Marković, Tanja Šljivar, Milena Minja Bogavac i Vida Ognjenović ${ }^{24}$. Podczas festiwalowych debat u progu nowego tysiąclecia zrodziło się pytanie, dokąd zmierza serbski dramat i jak instytucja Sterijino pozorje może wspierać jego rozwój oraz przeradzanie się tekstów w spektakle? Decyzja o organizowaniu regularnie ogłaszanego konkursu na najlepszy rodzimy współczesny tekst dramatyczny była pokłosiem idei transformacji festiwalu w 2006 roku $^{25}$. Dotychczas nagrodzone teksty, autorstwa: Mai Pelević, Branislavy Ilić, Filipa Vujoševicia, Petara Mihajlovicia, Sašy Večanskiego, Vojislava Savicia, Ljubišy Vićanovicia, Olgi Dimitrijević, Božidara Kneževicia, Zorana Pešicia Sigmy, Ivy Brdar i Filipa Grujicia ${ }^{26}$, zostały opublikowane

23 S. Bodroža, red., 2013: Biseri iz upravničkih fioka. Beograd, Ustanova kulture gradske opštine Stari Grad Parobrod.

24 Robotnicy umieraja z pieśnia na ustach (Radnici umiru pevajući) Olgi Dimitrijević (2012), Czarodziej (Čarobnjak) Fedora Šili (2013), Za mały dla mnie ten grób (Mali mi je ovaj grob) Biljany Srbljanović (2014), Smokobójcy (Zmajeubice) Mileny Marković (2015), Jesteśmy tymi, przed którymi przestrzegali nas nasi rodzice (Mi smo oni na koje su nas roditelji upozoravali) Tanji Šljivar (2016), Dystrykt Jami (Jami Distrikt) Mileny Minji Bogavac (2018) i Kozocyd (Kozocid) Vidy Ognjenović (2019). W 2017 roku jury zadecydowało, że przyznaje dwie nagrody: Nagrodę im. Sterii wszystkim uczestnikom oraz Specjalną Nagrodę im. Sterii dla publiczności 62. Festiwalu.

25 Dyrekcja Belgradzkiego Teatru Dramatycznego (Beogradsko dramsko pozorište) zdecydowała się później na podobny zabieg i ogłosiła w 2011 roku konkurs na debiut dramatyczny. Niestety, po trzech edycjach projekt nie był kontynuowany.

26 Może jesteśmy Myszką Miki (Možda smo mi Miki Maus) Mai Pelević (2007), Ciato (Telo) Branislavy Ilić (2008), Ronaldzie, zrozum mnie (Ronalde, razumi me) Filipa Vujoševicia (2008), Kronika robotnicza (Radnička hronika) Petara Mihajlovicia (2009), Przetworzone przestępstwo (Reciklirani zločin) Sašy Večanskiego (2010), Odejście w... (Odlazak u krasni) Vojislava Savicia (2011), Nieczyste sity (Nečiste sile) Ljubišy Vićanovicia (2013), Jak dobrze znowu cię widzieć (Kako je dobro videti te opet) Olgi Dimitrijević (2014), Ilustrowana encyklopedia zanikania (Ilustrovana enciklopedija nestajanja) 
na łamach czasopisma „Scena”, a później przeniesione na deski teatru (najczęściej jako koprodukcje festiwalu Sterijino pozorje i innych teatrów w kraju). Zamierzenia dotyczące wspomagania autorów na drodze, którą pokonują od procesu kształcenia ku profesjonalizacji, były zatem sukcesywnie i z powodzeniem $^{27}$ realizowane, a potwierdzeniem tego miała stać się podsumowująca antologia Nowy dramat serbski 2007-2015 (Nova srpska drama 2007-2015 ${ }^{28}$ ). Ponowna publikacja wyłonionych w drodze konkursu tekstów zestawionych w porządku chronologicznym była według Mariny Milivojević Mađarev uzasadnionym posunięciem, ponieważ ważne jest, aby nagrodzone sztuki, które przeniesiono już na deski teatru nie rozstały się z tym życiem, nie straciły swej widzialności i witalności, czyli żeby doczekały się kolejnych inscenizacji. Powinny być one prezentowane i promowane w formie tekstu, do którego się powraca i przy każdym podejściu inaczej się go percypuje, „bo żeby ożył on na scenie, musi być kiedyś przeczytany, a potem jeszcze raz i jeszcze raz [...]"29.

Wspomniany dramaturg, teatrolog i antologista Svetislav Jovanov również przyczynił się do podniesienia rangi propozycji artystycznych najmłodszych dramatopisarzy i dramatopisarek (często świeżo upieczonych absolwentów belgradzkiego Wydziału Sztuk Dramatycznych). Jako przewodniczący jury przyznającego - pod patronatem między innymi Ministerstwa Kultury Serbii - Nagrodę im. Borislava Mihajlovicia Mihiza za twórczość dramatopisarską, Jovanov miał styczność z najnowszą tego rodzaju produkcją i istotnie wpłynął na popularyzację wybranych tekstów. Dzięki jego operatywności powstała Antologia dramatów zdobywców Nagrody im. Mihiza (Antologija drama dobitnika Mihizove nagrade ${ }^{30}$ ) oraz seria książek $\mathrm{z}$ tekstami laureatów tej prestiżowej nagrody ${ }^{31}$.

Božidara Kneževicia (2015), Ulica samotnych samochodów (Ulica usamljenih automobila) Zorana Pešicia Sigmy (2016), Autostopowicze (Bacači prstiju) Ivy Brdar (2017), Nie przed 4:30 ani po 5:00 (Ne pre 4:30 niti posle 5:00) Filipa Grujicia (2018), Kołysanka dla Aleksii Rajčić (Uspavanka za Aleksiju Rajčić) Đorđa Kosicia (2019).

27 Zauważalne są tendencje do rozszerzania formuły, np. w związku z programem Europejska Stolica Kultury Nowy Sad 2021.

28 Z. Đerić, red., 2016: Nova srpska drama 2007-2015. Novi Sad, Sterijino pozorje.

29 M. Milivojević Mađarev, 2016: Novo iščitivanje prvonagrađenih drama. W: Nova srpska drama..., s. 356 .

30 K. Krnajski, S. Jovanov, red., 2015: Antologija drama dobitnika Mihizove nagrade. Kraljevo, Biblioteka „Pozorja” / Kulturni centar „Ribnica”. W zbiorze zostały zaprezentowane utwory autorów i autorek takich jak: Milena Marković, Maja Pelević, Marija Karaklajić, Milena Minja Bogavac, Milica Piletić, Jordan Cvetanović, Tanja Šljivar, Milan Marković, Danica Nikolić.

31 W latach 2006-2019 w ramach serii pod redakcją Svetislava Jovanowa ukazały się wybrane dramaty Mileny Marković, Mai Pelević, Mariji Karaklajić, Mileny Minji Bogavac, Milicy Piletić, Jordana Cvetanovicia, Tanji Šljivar, Milana Markovicia, Danicy Nikolić Nikolić, Olgi Dimitrijević, Branislavy Ilić i Dimitrije Kokanova. 
Czasopisma, które afirmują krajową produkcję dramatopisarską oraz teatralną, to przede wszystkim prężnie rozwijający się, dostępny również w formie elektronicznej periodyk z Nowego Sadu „Scena” (w każdym numerze pojawia się co najmniej jeden nowy dramat) oraz belgradzki „Teatron”32. Krytyczka teatralna Darinka Nikolić przytacza statystyki, z których wynika, że w XXI wieku więcej niż dwie trzecie publikowanych w czasopiśmie „Scena” tekstów dramatycznych przeobraża się w spektakle. Dzięki tej praktyce drzwi teatrów otwierają się również przed młodymi autorami i autorkami dramatów ${ }^{33}$.

Intensywny rozwój globalnej komunikacji i praktyka przekładowa także pozwoliły wybranym dramatom szybciej niż kiedykolwiek osiągnąć szeroki, nawet pozaterytorialny zasięg. Promocji tekstów najmłodszych dramatopisarzy podjęli się twórcy portali internetowych. Najbardziej kompleksową bazą oferującą dostęp do wielu utworów (również w tłumaczeniu na język angielski) i biogramów jest otwarte archiwum Nova drama ${ }^{34}$ (http://www.nova-drama.org. rs/otvorena-arhiva-nove-drame/) zarządzane przez Milana Markovicia Matthisa i wspierane przez szwedzki teatr FyraBen.

Obecnie coraz trudniejszym zadaniem jest delimitowanie różnic, opisywanie wielorakości oraz wszelkich stopni pośrednich, powiązań, wpływów i zapożyczeń między poszczególnymi kulturami ${ }^{35}$, co obowiązuje także w przypadku aktów kreacji na polu dramatu i teatru. Artystyczne granice Serbii otwierają się zgodnie z tokiem nieuniknionych procesów globalizacyjnych. Uwidacznia się to na różnych poziomach: jako podróże, rezydencje i warsztaty artystyczne, wymiana informacji, konfrontacja $z$ innymi postawami, dostęp do materiałów i artefaktów, budowanie niebywale drożnych i efektywnych transterytorialnych kanałów komunikacyjnych za sprawą mediów elektronicznych, co prowadzi do „demontażu geografii jako przestrzennej, terytorialnej bazy kultury” ${ }^{\text {36 }}$. Dzięki temu dochodzi do międzynarodowych korelacji, kooperacji i koprodukcji, powstają nowe jakości, które warto przenosić na nowy grunt, aby stały się źródłem kolejnych inspiracji. Przekład dramatów i wydawanie zbiorów za granicą jest

32 Czasopismo „Teatron” wydawane jest przez Muzeum Sztuki Teatralnej (Muzej pozorišne umetnosti).

33 D. Nikolić, 2015: Prepoznavanje novih tokova u srpskoj dramaturgii. „Scena”, nr 1/2, s. 54.

34 Celem projektu jest umożliwienie prezentacji najnowszej produkcji dramatopisarskiej. $\mathrm{Na}$ oficjalnej stronie teksty młodych dramatopisarzy i dramatopisarek zestawione są w dwóch bazach: elektronicznej — zbiorczej i selektywnej.

35 M. Golka, 2010: Imiona wielokulturowości. Warszawa, Warszawskie Wydawnictwo Literackie Muza, s. 55.

36 Z. Pucek, 2005: Arjun Appadurai i antropologia bez granic. W: A. Appadurai: Nowoczesność bez granic. Kulturowe wymiary globalizacji. Z. Pucek, tłum. Kraków, Universitas, s. XII-XIV. 
jednym z najskuteczniejszych sposobów promocji dramatopisarstwa na poziomie ponadlokalnym.

Należy zastanowić się, w jaki sposób charakteryzujące się dynamiką i otwartością dramatyczne, a często postdramatyczne lub nawet adramatyczne, teksty serbskich autorów i autorek ujmują kulturę, w której powstały, która je przechowuje i reaguje na nie, oraz jak będą funkcjonowały w odmiennej strefie geokulturowej? Dramatopisarze i dramatopisarki aktywni w Serbii bez wątpienia umieją wykorzystać możliwości własnego języka i tworzyć tzw. energię sceniczną, co doceniają także odbiorcy z innych obszarów językowych: tłumacze, wydawcy, czytelnicy, słuchacze, widzowie, realizatorzy, krytycy i badacze.

\section{Najnowszy dramat serbski w polskiej przestrzeni artystycznej}

Dla przeglądu, w którym integruję i interpretuję fakty dotyczące podjętego tematu, relewantne są także okresowe wzrosty zainteresowania polskich tłumaczy i wydawców twórczością dramatopisarzy i dramatopisarek pochodzących z Serbii. Od kilku dziesięcioleci miesięcznik teatralny „Dialog” stanowił główną przestrzeń prezentacji wybranych serbskich utworów dramatycznych ${ }^{37}$. Polska publiczność zawdzięcza dostęp do tekstów współczesnych autorów i autorek z terenów byłej Jugosławii wybitnej tłumaczce oraz redaktorce „Dialogu” Dorocie Jovance Ćirlić. Należy zaznaczyć, że dzięki jej pracy translatorskiej na naszych scenach gościły także niepublikowane jeszcze w Polsce sztuki. Odwołując się do spostrzeżeń przekładoznawczyni Katarzyny Majdzik ${ }^{38}$, chciałabym dodać, że Dorota Jovanka Ćirlić, a także inni tłumacze promujący tę twórczość, uznani mogą być za „ambasadorów”, których celem działalności jest w równej mierze walka ze stereotypowymi wyobrażeniami na temat literatur południowosłowiańskich, a w tym wypadku, specyficznej produkcji dramatopisarskiej i scenicznej.

Koncentrację uwagi na serbskim dramacie w naszym kraju można dostrzec w 2012 roku, kiedy to na rynku księgarskim pojawiły się aż dwie niezależnie

37 Publikacji w „Dialogu” doczekały się przekłady sztuk Đorđe Lebovicia i Aleksandra Obrenovicia, Jovana Hristicia, Velimira Lukicia, Veljko Radovicia, Dušana Kovačevicia, Ljubomira Simovicia, Borislava Pekicia, Aleksandra Popovicia, Biljany Srbljanović, Mileny Marković, Stojana Srdicia i Mai Pelević.

38 K. Majdzik, 2013: Literatura chorwacka i jej polscy ambasadorzy. Uwagi do bibliografii przekładów literatury chorwackiej w Polsce w latach 2007-2013. „Przekłady Literatur Słowiańskich", nr 5, cz. 2, s. 47. 
wydane propozycje, które miały na celu zapoznanie polskich odbiorców z najnowszymi osiągnięciami uznanych już w Serbii autorów i autorek. Krakowska antologia Postpolityczność ukazała się w serii „Dramat Współczesny”, firmowanej przez Katedrę Dramatu Uniwersytetu Jagiellońskiego i wydawnictwo Panga Pank ${ }^{39}$. Dwutomowy wybór Serbska ruletka został natomiast równolegle wydany w serii Bibliotheca: Alia Universa Uniwersytetu Śląskiego w Katowicach i jest dostępny w dwóch wersjach: papierowej oraz elektronicznej (w bibliotece cyfrowej i wypożyczalni IBUK.pl) ${ }^{40}$. Jak zauważyl jeden ze współredaktorów, Leszek Małczak, projekty, których efektami były przywołane książki oraz wyrastające z nich przedstawienia teatralne, sprawiły że w ostatnich latach spośród sztuk powstałych w byłej Jugosławii to właśnie współczesny dramat serbski stał się najbardziej znany w Polsce ${ }^{41}$. Pozycje te zapełniły z pewnością pewną lukę, ponieważ nawet czasopismo „Dialog” po roku 2000 incydentalnie dostarczało odbiorcom dramaty Biljany Srbljanović i Dušana Kovačevicia, i to tylko do 2008 roku. Ponadto zespoły redaktorów i tłumaczy pracujące nad Postpolitycznością i Serbską ruletka umożliwiły Polakom konfrontację ze zbyt generalizowaną, a w zasadzie mało im znaną twórczością, co mocno wpisywało się we współczesne tendencje percepcji inności ${ }^{42}$.

Odchodząc od wartościującego porównania tych dwóch publikacji, chciałabym zwrócić jedynie uwagę na odmienność korpusu tekstów, charakteru oraz "losów” tych propozycji wydawniczych. Powtórzę za Leszkiem Małczakiem, że jednotomowy wybór Gorana Injaca (wówczas lektora języka serbskiego na Uniwersytecie Opolskim) zawiera 6 utworów, z których połowa była już znana polskim widzom $\mathrm{z}$,oryginalnych" realizacji ${ }^{43} \mathrm{w}$ wykonaniu belgradzkich zespołów z Jugosłowiańskiego Teatru Dramatycznego (Barbelo, o psima i deci ${ }^{44}$ oraz Hadersfild $^{45}$ ) i Atelje 212 (Pomorandžina kora ${ }^{46}$ ) zaproszonych w 2009 roku na III edycję Międzynarodowego Festiwalu Teatralnego Demoludy. Należy

39 G. Injac, red., 2011: Postpolityczność. Antologia nowego dramatu serbskiego. Kraków, Panga Pank.

40 A. Cielesta, L. Małczak, D. Zwierzchowska, red., 2011: Serbska ruletka. Dramat serbski po 1995 roku...

41 L. Małczak, 2014: Przekłady literatury serbskiej w Polsce w latach 2007-2013. „Przekłady Literatur Słowiańskich", nr 5, cz. 2, s. 146.

42 M. Bogusławska, 2017: Kulturowe aspekty recepcji serbskiego dramatu..., s. 12.

43 L. Małczak, 2014: Przekłady literatury serbskiej w Polsce w latach 2007-2013..., s. 146.

44 Barbelo, o psima i deci, tekst: B. Srbljanović, reż. D. Mijač, JDP; Barbelo, o psach i dzieciach, tłum. D.J. Ćirlić.

45 Hadersfild, tekst: U. Šajtinac, reż. A. Čizholm, JDP; Huddersfield, tłum. Ł. Wieczorek, G. Đurđev-Małkiewicz.

46 Pomorandžina kora, tekst: M. Pelević, reż. G. Marković, Atelje 212; Skórka pomarańczowa, tłum. D.J. Ćirlić. 
podkreślić, że teksty Srbljanović i Pelević doczekały się nowego opracowania dramaturgicznego i przeniesienia do polskich teatrów. Co ciekawe, w przypadku Barbelo, o psach i dzieciach można odnotować dwie niezależne premiery ${ }^{47}$, które zbiegły się z publikacją antologii w 2011 roku, a Skórka pomarańczowa dotarła na sceny polskie również $\mathrm{w}$ dwóch wariantach - jako czytanie performatywne ${ }^{48}$ oraz spektakl ${ }^{49}$. Pozostałe trzy teksty to nowe przekłady, z których jeden, Halflife Filipa Vujoševicia, został wykorzystany do przygotowania czytania dla publiczności ${ }^{50}$. Pozycja autorów ${ }^{51}$ oraz zakotwiczenie wybranych przez Injaca sztuk w ich źródłowym świecie teatralnym nie pozostają tu bez znaczenia i być może przesądziły o dobrym starcie wybranych serbskich sztuk w nowej przestrzeni.

Projekt przekładoznawczy Serbska ruletka umożliwił z kolei odbiorcom zetknięcie się z nieznanymi zupełnie w Polsce tekstami. Jedna ze sztuk zamieszczonych w zbiorze - Statek dla lalek Mileny Marković, na podstawie której powstały dwa, kultowe wręcz, serbskie spektakle - została wystawiona $\mathrm{w}$ krakowskim Teatrze Barakah ${ }^{52}$. Również inne dramaty ${ }^{53}$ zaprezentowane na $^{2}$ ponad 450 stronach wyboru były w Serbii nagradzane i włączane do repertuarów teatralnych, jednak jako przekłady przeszły w Polsce właściwie bez echa.

Autorzy antologii zdecydowali się na selekcję utworów, którym nie można zarzucić, że są zbyt hermetyczne ani, z drugiej strony, oderwane od specyficznego kontekstu. Istniało zatem spore prawdopodobieństwo, że zanurzą się one w kulturę polską i istotnie ją wzbogacą, ponieważ staną się impulsem uruchamiającym nowe projekty artystyczne. Można było spodziewać się nadejścia

47 Barbelo, o psach i dzieciach, tekst: B. Srbljanović, reż. A. Augustynowicz, tłum. D.J. Ćirlić, Teatr im. Stefana Jaracza w Łodzi, 2011; Barbelo, o psach i dzieciach, tekst: B. Srbljanović, reż. M. Bogajewska, Teatr Bagatela, Kraków, 2011.

48 Skórka pomarańczowa, tekst: M. Pelević, reż. C. Iber, tłum. D.J. Ćirlić, Teatr Polski we Wrocławiu, 2013.

49 Skórka pomarańczowa, tekst: M. Pelević, reż. M. Warsicka, tłum. D.J. Ćirlić, Teatr im. S. Jaracza w Olsztynie, 2014.

50 Halflife, tekst: F. Vujošević, reż. K. Popiołek, tłum. G. Injac, J. Wichowska, Teatr Polski we Wrocławiu, 2012.

51 Oprócz wcześniej wymienionych w tomie znajdują się też sztuki Mileny Marković (Świetlisty las - Šuma blista) i Mileny Minji Bogavac (Ballerina / Gamma Cas Balerina / Gamma Cas).

52 Statek dla lalek, tekst: M. Marković, reż. A. Nowicka, tłum. A. Cielesta, Teatr Barakah, Kraków 2011, re-premiera 2014.

53 Poza dramatem Mileny Marković zebrano tu siedem utworów autorstwa Svetislava Basary (Dolce Vita), Miroljuba Nedovicia (Kraina ciemności - Tamni vilajet), Mirjany Ojdanić (Ślad ludzkich zębów - Trag ljudskih zuba), Nebojšy Romčevicia (Karolina Neuber - Karolina Nojber), Gorana Markovicia (Willa Sachino - Vila Sašino), Mileny Minji Bogavac (Czerwona. Seks i konsekwencje - Crvena. Seks i posledice), Marii Karaklajić (Twarz ze szkła - Lice od stakla) i Mai Pelević (Może jesteśmy Myszka Miki - Možda smo Miki Maus). 
okresu ożywionych kontaktów teatralnych między Polską a Serbią oraz intensyfikacji lektury tekstów i jej scenicznych realizacji, zwłaszcza że nowy dramat serbski bywa już rzadziej etykietowany jako sztuka autorów i autorek należących do „problematycznych mniejszości o złej reputacji” ${ }^{54}$. W toku przygotowań takich przeglądów, panoram i zestawień trudno jest jednak przewidzieć, czy zasilenie kolejnymi, reprezentacyjnymi - zdaniem redaktorów - tekstami będzie miało swoje pozytywne konsekwencje na gruncie polskim. Zmieniające się stale okoliczności i klimat polityczny mogą przecież drastycznie zaważyć na przychylności czytelników, badaczy i realizatorów teatralnych. Poza tym bez pewnej stymulacji ich entuzjazm przygasa, ponieważ nawet zbiór tekstów, które posiadają potencjalnie moc długofalowego i szerokozakresowego oddziaływania, rzadko ma szansę sam się obronić i nie zginąć w gąszczu napływających stale treści. Pewne jest, że praktyka przekładowa, zwłaszcza twórczości pisanej w małym języku, która nie ma przez to odpowiedniej siły przebicia, nie może być oderwana od aktywnych działań promocyjnych.

W latach 2012-2019 dramat pozostał w kręgu zainteresowania polskich odbiorców, jednak ulegało ono nieznacznym wahaniom. W przypadku publikacji przekładów ponowny zwrot ku serbskiemu dramatowi jest zauważalny na łamach „Dialogu” dopiero w 2014 roku, kiedy poświęcono w nim miejsce artystycznym opracowaniom wybuchu I wojny światowej. W numerze listopadowym pojawiły się wtedy utwory znanych już w Polsce autorek - Biljany Srbljanović i Mileny Marković. Dopiero kolejne lata przyniosły propozycje mniej popularnego Stojana Srdicia - Moje dziecko ${ }^{55}$ (Moje dete) oraz rozpoznawalnych już w polskim świecie teatralnym autorek: Mai Pelević - BelgradBerlin $^{56}$ (Beograd-Berlin), Mileny Marković - Dzieci radości ${ }^{57}$ (Deca radosti) i Tanji Šljivar - Ale miasto mnie chroniło ${ }^{58}$ (Ali grad me je štitio). Wszystkie wyeksponowane w tym okresie utwory doczekały się serbskich premier teatralnych, a w Polsce — na razie żadnej. W dziale „Nowe sztuki” polecone uwadze zostały z kolei dramaty Miloša Nikolicia - Osiemnaście Kotów i Blacharz Herman Brun (Osamnaest Mačaka i Limar Herman Brun), Olgi Dimitrijević (we współautorstwie z Mają Pelević, Slobodanem Obradoviciem, Tanją Šljivar, Vedraną Klepicą) - Lepa Brena Project (Lepa Brena Prodžekt), Tanji Šljivar - Śmierć

54 S. Srbljanović, 2008. Za: S. Savić, 2008: Sytuacje rodzinne i inne. M. Wierzbicka, tłum. „Dialog”, nr 9, s. 125.

55 S. Srdić, 2017: Moje dziecko. D.J. Ćirlić, tłum. „Dialog”, nr 12. Premiera teatralna: Beogradsko dramsko pozorište, 2016, reż. A. Đorđević.

56 M. Pelević, 2018: Belgrad-Berlin. D.J. Ćirlić, tłum. „Dialog”, nr 7/8. Premiera teatralna: Zvezdara Teatar, 2005, reż. Ksenija Krnajski.

57 M. Marković, 2019: Dzieci szczęścia. D.J. Ćirlić, tłum. „Dialog”, nr 1.

58 T. Šljivar, 2020: Ale miasto mnie chroniło. D.J. Ćirlić, tłum. „Dialog”, nr 3. 
wędrownej handlarki. Monolog dla Europy (Smrt trgovačke putnice. Jedan monolog za Evropu), Stefana Tajbla - Fleischmannowie (Flajšmanovi), autorstwa duetu Ana Isaković i Ramiz Huremagić - Czy chciałabyś jeszcze kiedyś się spotkać ( Da li bi htela da se još ponekad nađemo) i Dušana Kovačevicia - Kumowie (Kumovi), na podstawie którego powstało słuchowisko w Teatrze Polskiego Radia ${ }^{59}$.

$\mathrm{Na}$ tle tekstów promujących z założenia konkretne serbskie dramaty należy wyróżnić także artyku1 ${ }^{60}$ opublikowany w specjalnym, belgradzkim numerze czasopisma „Rita Baum”, przybliżający wydarzenia artystyczne koordynowane przez Fundację Hartefakt. Gabriela Abrasowicz i Berenika Nikodemska zamieściły w nim także krótkie fragmenty tekstów dramatycznych (w swoim tłumaczeniu), które były fundamentem najgłośniejszych (ko)produkcji teatralnych realizowanych w tym ośrodku: Robotnicy umieraja z pieśnia na ustach ${ }^{61}$ autorstwa Olgi Dimitrijević, Drapanie albo Jak zabiła się moja babcia ${ }^{62}$ Tanji Šljivar ${ }^{63}$, Za mały dla mnie ten grób ${ }^{64}$ Biljany Srbljanović, Ronaldzie, zrozum $m n i e^{65}$ Filipa Vujoševicia.

Poza obiegiem wydawniczo-czytelniczym również powstają przekłady tekstów dramatycznych udostępniane realizatorom scenicznym, np. na potrzeby festiwalu teatralnego lub konkretnego projektu. Wydarzenie artystyczne, jakim jest Międzynarodowy Festiwal Teatralny Demoludy organizowany w Teatrze im. Stefana Jaracza w Olsztynie, na pewno przyczyniło się do wzrostu świadomości polskich odbiorców na temat dramatu serbskiego. Po prawdziwej uczcie teatromana, jaką była wspomniana edycja festiwalu w 2009 roku pod hasłem „Nowa dramaturgia narodów byłej Jugosławii”, polscy widzowie nie mieli częstego kontaktu z propozycjami teatrów z Serbii na podstawie współczesnych sztuk ani z tekstami prezentowanymi zgodnie $\mathrm{z}$ formułą czytań performatywnych. W programach olsztyńskich występów znalazły się „czytanki” zrealizowane

59 Kumowie, tekst: D. Kovačević, reż. J. Kukuła, tłum. G. Walczak, 2018.

60 G. Abrasowicz, B. Nikodemska, 2014: H/artefaktyczny angaż społeczny. „Rita Baum”, nr 34, s. 58-63.

61 Radnici umiru pevajući, tekst: O. Dimitrijević, reż. A. Nikolić, Hartefakt i Bitef teatar, 2011.

62 Grebanje ili kako se ubila moja baka, tekst: T. Šljivar, reż. S. Spahić, Hartefakt, Bitef teatar, BNP Zenica, 2012.

63 Pochodząca z Banja Luki (Republika Serbska w Bośni i Hercegowinie) Tanja Šljivar jest aktywna zarówno w ojczyźnie, jak i w Serbii, w związku z tym włączana jest do kręgu autorek serbskich oraz bośniacko-hercegowińskich.

64 Mali mi je ovaj grob, tekst: B. Srbljanović, reż. D. Mustafić, Hartefakt, Bitef teatar, Kamerni teatar '55, Kazalište Ulysses, Testament films, Internacionalni teatarski festival MESS, 2014.

65 Ronalde, razumi me, tekst: F. Vujošević, reż. A. Tomović, Narodno pozorište u Beogradu, 2009. 
na podstawie tekstów Tanji Šljivar Drapanie albo Jak zabiła się moja babcia ${ }^{66}$ (Grebanje ili kako se ubila moja baka) i Nedy Radulović Painkillers ${ }^{67}$. Czytania w wykonaniu autorów stanowiły natomiast segmenty spotkania „Bałkańskie mosty” w Teatrze Śląskim w Katowicach podczas XXVII Festiwalu Ars Cameralis w 2018 roku. Publiczność miała okazję usłyszeć monodram Tanji Šljivar Śmierć wędrownej handlarki. Monolog dla Europy ${ }^{68}$ (Smrt trgovačke putnice. Jedan monolog za Evropu) przedstawiony przez samą autorkę, a Milena Minja Bogavac stworzyła inscenizację fragmentu swojego trudnego do sklasyfikowania utworu Miłość niech idzie w jasna... ${ }^{69}$ (Ljubav se nosi u tri...), oscylującego między dramatem i prozą.

W 2014 roku na XVIII Międzynarodowym Festiwalu Teatrów dla Dzieci i Młodzieży Korczak w Warszawie, a później na wspomnianych już Demoludach gościł spektakl Maja i ja i Maja ${ }^{70}$ na podstawie sztuki Milana Markovicia. Z kolei w 2016 roku do Wrocławia zawitał belgradzki teatr Plavo Pozorište ze swoim projektem Marzenie - historia z Terezina (Sanjarenje - priča iz Terezina) w reżyserii Nenada Čolicia. Zespół był gościem Olimpiady Teatralnej organizowanej przez Instytut im. Jerzego Grotowskiego.

Przytoczone informacje skłaniają do refleksji nad poszukiwaniem bardziej optymalnego sposobu wkomponowania serbskiego dramatu w polski krajobraz artystyczny. Jak już wspomniałam, sama dostępność przełożonego tekstu jest często niewystarczająca, ponieważ, choć jest on niewątpliwie istotnym świadectwem aktywności artysty, czasem czeka zbyt długo na stosowny moment, żeby trafić w odpowiednie ręce. Dążeniem autorów jest przecież wywołanie takiego sprzężenia zwrotnego, aby utwór dzięki odpowiedzi napływającej ze strony odbiorców przekształcił swój sens. Cyrkulacja, otwarcie się na przepływy oraz tworzenie ogniw w łańcuchu komunikatów jest esencją kultury, ale wymaga to sprzyjających warunków.

Coraz silniejsze jest przekonanie, że dramat może być punktem wielokrotnych i wielorakich powrotów. Odkryto wiele sposobów obcowania z nim, w zależności od tego, jakie dyrektywy zawarte w utworze będzie respektował odbiorca. Który z nich najpełniej odpowiada jego „zawieszeniu” między różnymi porządkami? Jak uniknąć jego klasyfikowania jako dramat teatralny

66 Drapanie albo Jak zabiła się moja babcia, tekst: T. Šljivar, reż. M. Wdowik, tłum. G. Abrasowicz, B. Nikodemska, Teatr im. S. Jaracza w Olsztynie, 2015.

67 Painkillers, tekst: N. Radulović, reż. P. Kurzawa, tłum. G. Abrasowicz, B. Nikodemska, Teatr im. S. Jaracza w Olsztynie, 2016.

68 T. Šljivar, Śmierć wędrownej handlarki. Monolog dla Europy, tłum. G. Abrasowicz, M. Koch.

69 M. Bogavac, Ljubav se nosi u tri... (fragmenty), tłum. E. Sobalkowska.

70 Maja i ja i Maja, tekst: M. Marković, reż. A. Suša, Bitef teatar, tłum. G. Abrasowicz. 
(do wystawiania) lub nieteatralny (do czytania)? Jak z jednej strony zapobiec wtłaczaniu go w ramy literatury i hamowania jego aktywności (ze względu na obniżoną chłonność teatrów, mały budżet itd.), a z drugiej uwolnić go spod presji wymagań spektaklu? Być może istnieje wyjście z tego impasu.

\section{Skala przeznaczeń dramatu a ograniczenia}

W obliczu zmian twórczość dramatopisarska posiada status swoistej „sieroty” — nie jest już przyjmowana pod skrzydła literatury, nie jest też nierozerwalnie związana $\mathrm{z}$ teatrem, a nawet może zmaterializować się poza sceną ${ }^{71}$. Dramat jest więc wpisany między tekst a działania, jest czymś stworzonym i stwarzającym jednocześnie i przez to właśnie zjawiskiem tak trudnym do zidentyfikowania ${ }^{72}$. Odbiorca musi wyciągnąć konsekwencje z tego nieoczywistego dziś statusu dramatu, czyli sprzężenia dramatyczności jako literackiej kategorii rodzajowej $\mathrm{z}$ teatralnością pojętą jako tryb wykonawczy utworu ${ }^{73}$. Żaden $\mathrm{z}$ aspektów (ani literacki, ani teatralny) nie jest wykluczany, ponieważ uzupełniają się one i kumulują, co wpływa na wielość przeznaczeń dramatu.

Ta granica między dramatem i teatrem jest różnie postrzegana. Obecnie staje się coraz mniej wyraźna, a przejście między tymi dwiema przestrzeniami rozciąga się na wiele stopni. W praktyce wielopoziomowość realizacji dramatu obejmuje liczne formy, do których teoretyczka literatury Magdalena Saganiak zaliczyła: czytanie ciche, czytanie na głos (sobie lub komuś), reżyserowana próba w teatrze, autonomiczne czytanie sceniczne/performatywne (nie jako etap pośredni), słuchowisko radiowe, teatr rapsodyczny, teatr dramatyczny ${ }^{74}$. Paleta dookreśleń, które towarzyszą dramatowi rozpościerającemu się między biegunami: od braku opcji realizacji scenicznej do skrajnie pragmatycznego i funkcjonalnego nastawienia na spektakl, jest zatem bardzo bogata.

W strukturze i poetyce tekstu dramatycznego tkwi potencjał inscenizacyjny, który nie znika, nawet jeśli dramat jest wyłącznie czytany, a nie

71 N. Nelević, 2012: Siroti dramski tekst: novi pristupi pozorištu. „Gest”, nr 3, s. 70.

72 A. Grabowski, J. Kopciński, 2014: Dramat - przedmiot do odnalezienia (słowo wstępne). W: A. Grabowski, J. Kopciński, red.: Dramat w tekście - tekst w dramacie. Warszawa, Wydawnictwo Instytutu Badań Literackich PAN, s. 11.

73 D. Ratajczakowa, 2006: W krysztale i w płomieniu. Studia i szkice o dramacie i teatrze. Cz. 2. Wrocław, Wydawnictwo Uniwersytetu Wrocławskiego, s. 9.

74 M. Saganiak, 2014: Lektura dramatu - czyli o możliwej wyższości czytelnika dramatu nad widzem spektaklu. W: A. Grabowski, J. Kopciński, red.: Dramat w tekście..., s. 32. 
wystawiany $^{75}$, ponieważ może z powodzeniem funkcjonować także w wyobraźni czytelnika. Przeobraża się on w przedmiot uzależniony od indywidualnych predyspozycji czytającego i przystosowany jest do jego kreacyjnych potrzeb ${ }^{76}$. Czytelnik jest zdolny uchwycić pewną liczbę aspektów scenicznych dzieła i stara się stworzyć w wyobraźni obraz możliwie ukonkretniony, ale może się to też ograniczyć jedynie do porządkowania i scenicznej schematyzacji podstawowych komponentów fenomenu teatralnego ${ }^{77}$. Kreowana przez odbiorcę imaginacyjna "druga rzeczywistość", hipotetyczny tekst widowiskowy dramatu, jest rezultatem scalenia literatury i teatru na podłożu autorskiego metatekstu, a więc dzięki szansie, jaką otwiera przed teatrem literatura. Jak zauważyła teatrolożka i dramatolożka Dobrochna Ratajczakowa, już w fazie lektury (być może w sposób niedoskonały) to, co dramatyczne, przekształca się w to, co teatralne. Ujawniają się wówczas aspekty wykonawcze struktur literackich, przełamana zostaje opozycja między tekstem a widowiskiem ${ }^{78}$. W trakcie spektaklu „uważny widz ma sposobność i przyjemność zarazem porównywać swój prywatny teatr wyobraźni (zbudowany w lekturze) ze sceniczną realizacją dramatu" "79.

Możliwe jest zatem istnienie takiej lektury dramatu, która jest bliska ożywieniu scenicznemu. Wtedy właśnie odbiorca dzięki uważności, świadomości i wyobraźni wchodzi w wymagane doświadczenie ${ }^{80}$. Istnieją oczywiście teksty, które wyróżnia ta szczególna predyspozycja. Wiele utworów serbskich dramatopisarzy i dramatopisarek powstałych na początku XXI wieku zalicza się do tej grupy. Dramaty te są intergatunkowe, nie przypominają już wyważonych homogenicznych konstrukcji, bo jako takie okazują się optymalnym medium artystycznego transponowania rzeczywistości. Wyrywając się z ciasnego gorsetu literackich ograniczeń, jakie dyktował klasycznie rozumiany tekst dramatyczny, wpisują się one w szersze tendencje konstruowania udramatyzowanych esejów, niekoniecznie z enigmatycznym potencjałem scenicznym (który dla grupy autorów wcale nie jest priorytetem), ale wykazujących wyjątkową podatność na opracowanie w postaci czytania performatywnego.

Po przesunięciu punktu ciężkości z dzieła na sam proces jego tworzenia i recepcji, a także na wzajemną relację między sceną i publicznością, co

75 B. Bibik, 2016: Od Autorki. W: Eadem: Translatoris vestigia: Projekcje inscenizacyjne wybranych polskich tlumaczy Orestei Ajschylosa. Toruń, Wydawnictwo Naukowe Uniwersytetu Mikołaja Kopernika, s. 18.

76 D. Ratajczakowa, 2006: $W$ krysztale i w płomieniu..., s. 10.

77 Ibidem, s. 13-14.

78 Ibidem, s. 15.

79 E. Bal, 2015: Jak działać przekładami? O tłumaczeniu tekstów dla teatru w kontekście performatywnego zwrotu w humanistyce. „Przekładaniec”, nr 31, s. 37.

80 M. Saganiak, 2014: Lektura dramatu..., s. 47. 
spowodował zwrot performatywny sprzed kilku dekad ${ }^{81}$, teksty dramatyczne

196 rzadziej stanowią wewnętrznie zamknięte i spójne utwory literackie. Najnowszy dramat serbski funkcjonuje wprawdzie na poziomie kompletnego tekstu (którego nie należy utożsamiać $\mathrm{z}$ lesedrama), aby wejść w powszechny obieg literatury, ale czasem pozostaje wyłącznie niedomkniętym, otwartym na interwencje i ostatecznie bardziej wędrującym z rąk do rąk niż publikowanym szkicem spektaklu lub coraz bardziej popularnego czytania performatywnego.

Czytanie tekstu w obecności publiczności jest osobnym fenomenem, który stanowi inherentną część systemu praktyk okołoteatralnych ${ }^{82}$. Wywodzi się ono $\mathrm{z}$ dwóch systemów: teatralno-performatywnego oraz dramatycznego, rywalizujących i dopełniających się zarazem. Wyodrębnić można przedsięwzięcia czerpiące silniej z języka teatru oraz takie, które poprzez swoją minimalistyczną formę pozwalają doświadczyć elementów systemu dramatycznego ${ }^{83}$. Koncepcja, która zakłada tworzenie trzeciej przestrzeni, swoistego złotego środka, doskonale współgra $\mathrm{z}$ dynamiką nowych serbskich dramatów. To działanie łączące różne rodzaje percepcji (wypowiedzi konstytuowanej w warstwie brzmieniowej i znaczeniowej, ale też treści, których odbiór angażuje inne zmysły) jest trudne do klasyfikacji i na tyle nieustabilizowane, że jego granice gatunkowe są płynne i za każdym razem wytyczane na nowo ${ }^{84}$. Nie powinno być ono traktowane jako przed-przedstawienie lub etap $\mathrm{w}$ doskonaleniu spektaklu, a raczej jako niezależny tryb realizacji ${ }^{85}$, który ze względu na swoją międzysystemowość, "kontrolowaną swobodę" ${ }^{86}$ oraz minimalizm w sposób atrakcyjny rozszerza ofertę teatrów i centrów kultury. Z uwagi na czynniki ekonomiczne to często jedyna opcja urzeczywistnienia planów publicznej prezentacji dramatu. Dodatkową motywacją do podjęcia decyzji o organizacji czytania jest też reprezentacja i percepcja obciążona prawdopodobnie w mniejszym stopniu od teatru pośredniością i spowolnieniem refleksji dotyczących społeczno-politycznych tematów ${ }^{87}$.

81 E. Bal, 2015: Jak działać przekładami?..., s. 37.

82 O. Braszczyński, 2014: Wstęp do myślenia o performatywnym czytaniu dramatu. W: A. Grabowski, J. Kopciński, red.: Dramat w tekście..., s. 53.

83 Ibidem, s. 50.

84 Ibidem, s. 52.

85 Ibidem, s. 54.

86 Jak zauważył Oskar Braszczyński, istotą czytania performatywnego jest estetyka szki$\mathrm{cu}$ - lekka, zewnętrznie swobodna, ale wewnętrznie spójna i rygorystyczna. Ibidem, s. 59.

87 H.-T. Lehmann, 2004: Teatr postdramatyczny. D. Sajewska, M. Sugiera, tłum. Kraków, Księgarnia Akademicka, s. 317. 


\section{Zamiast podsumowania - jeszcze jedno spojrzenie na wkład (polskich) tłumaczy w przekład i upowszechnianie (serbskich dramatów)}

W analizach dotyczących przekładu badano nierzadko zagadnienie przyjmowania podczas działań translatorycznych perspektywy czy też praktyki czytania w odniesieniu do podwójnej tożsamości dramatu (choć pojęcie dwoistości przestaje być kompletne). Rozróżnianie tłumaczy literackich i teatralnych jest wprawdzie podziałem schludnym $\mathrm{z}$ punktu widzenia teorii, jednak dość problematycznym dla praktyków. Moim zamierzeniem nie jest zagłębianie się w trudną sztukę przekładu dramatu i metodologię transformacji zapisanych znaczeń w sensy sceniczne. Pragnę jedynie uwypuklić konieczność znacznego rozszerzenia podejścia do tej kwestii. Tłumacze powinni starać się dać wyraz wielowymiarowości nowego dramatu pozbawionego dziś niepodważalnych cech dystynktywnych (co wynika z jednoczesnego osadzenia w świecie literatury, teatru, czytania scenicznego). Oznacza to próby nadążania za transformacją utworu dramatycznego i uwzględniania różnych prawdopodobnych płaszczyzn jego rozwinięcia. Aby to osiągnąć, tłumacze działają w poprzek granic gatunków i dyscyplin, przekraczają bariery własnej kultury, języka i często osobowości ${ }^{88}$. Jednocześnie w dalszym ciągu spoczywa na nich obowiązek, aby uchwycić przynależność utworu „do dwóch kultur: źródłowej oraz tej, w której dokonywany jest przekład”89. Świadomość tłumacza dotycząca literackiego i teatralnego wymiaru dzieła, a także jego wiedza, wyobraźnia i intuicja ${ }^{90}$ decydują o charakterze opracowania i stopniu ukonkretnienia oraz o zawarciu w przekładzie pewnej projekcji inscenizacyjnej, która wypływa $\mathrm{z}$ wizji autora.

W dotychczasowych tłumaczeniach dramatów serbskich na język polski ustalenia te były z pewnością respektowane. Pomimo ilościowego i jakościowego bogactwa materiału wciąż odczuwalny jest niedosyt działań polegających na przeniesieniu tekstu na poziom sceniczny czy performatywny. Trafnie zaobserwował to urodzony w Belgradzie i aktywny w Polsce reżyser Nono Dragović:

Teatr polski zajęty rodzimą codziennością i sobą, a także [...] zapatrzony prawie wyłącznie na Zachód, słabo dostrzega wartości i tematykę południowosłowiańskich

88 B. Tokarz, 2006: Model przekładu a stereotyp płci. W: P. Fast, red.: Płeć w przekładzie. Katowice, Wydawnictwo Śląsk-Częstochowa, Wydawnictwo Wyższej Szkoły Lingwistycznej, s. 9.

89 J. Niziołek, 2014: Cztery razy „Don Juan”: polskie dwudziestowieczne przekłady Moliera. Kraków, Wydawnictwo Naukowe Uniwersytetu Pedagogicznego, s. 21.

90 B. Bibik, 2016: Od Autorki..., s. 18. 
dramatów. Utworów, [...] na pewno mu bliższych i bardziej zrozumiałych od tych, tak modnych i tak szeroko obecnych w teatrze polskim — dzieł najnowszej dramaturgii europejskiej ${ }^{91}$.

Dla wielu odbiorców teatr ma stać się wentylem pozwalającym odreagować frustrację, zwierciadłem ich codziennego życia, przestrzenią, w której możliwe są symptomatyzacja zjawisk i krytyczno-polityczne oddziaływanie. Serbskim twórcom udaje się w dużej mierze sprostać tym wymaganiom. Nowe teksty, skrypty, partytury stanowią szansę na trafniejszą artykulację ledwie wyczuwalnych problemów, potrzeb, oczekiwań, jak również na stworzenie oraz nadanie pełniejszego i bardziej istotnego komunikatu z odpowiednim ładunkiem myślowym $^{92}$. Wiąże się to z podejmowaniem szerokiego spektrum bieżących tematów, będących przedmiotem żywego zainteresowania opinii publicznej, czyli publiczności. To swoista walka o zaangażowanie odbiorców, a tym samym przeciw sztuce wyalienowanej i nieużytecznej społecznie. Współgra to niewątpliwie z zamierzeniami polskich twórców. Waloryzacja tekstów serbskich dramatopisarzy i ich upowszechnianie podsyci być może potrzebę poszukiwań nowych jakości oraz przekraczania materialnych i symbolicznych granic, co zaowocuje nowymi projektami - na przykład czytaniami performatywnymi (na uwagę zasługuje tu gwałtowna, wywołana pandemią COVID-19, zmiana profilu odbioru i uczestnictwa realizowanego poprzez nowe media), które sprawią, że zarzuty podobne do tych wyrażonych przez Dragovicia nie będą miały już racji bytu.

\section{Literatura}

Abrasowicz G., 2016: Dramat ciała, ciało $w$ dramacie. Twórczość serbskich i chorwackich dramatopisarek $w$ latach 1990-2010. Wrocław, Atut.

Abrasowicz G., Nikodemska B., 2014: H/artefaktyczny angaż społeczny. „Rita Baum", nr 34, s. 58-63.

Bal E., 2015: Jak działać przekładami? O tłumaczeniu tekstów dla teatru w kontekście performatywnego zwrotu w humanistyce. „Przekładaniec”, nr 31, s. 31-54.

Bibik B., 2016: Od Autorki. W: Eadem: Translatoris vestigia: Projekcje inscenizacyjne wybranych polskich tłumaczy Orestei Ajschylosa. Toruń, Wydawnictwo Naukowe Uniwersytetu Mikołaja Kopernika, s. 9-34.

91 N. Dragović, 2009: Dramaty Aleksandra Popovicia. Głos reżysera. „Południowosłowiańskie Zeszyty Naukowe. Język - Literatura - Kultura”, nr 6, s. 196.

92 P. Demirski, 2015: Teatr dramatopisarzy..., s. 6. 
Bodroža S., red., 2013: Biseri iz upravničkih fioka. Beograd, Ustanova kulture gradske opštine Stari Grad Parobrod.

Bogusławska M., 2017: Kulturowe aspekty recepcji serbskiego dramatu w polskim teatrze współczesnym. „Studia Litteraria Universitatis Iagellonicae Cracoviensis", nr 12, z. 1, s. 1-13.

Bošković V., red., 2012: Prst. Zbirka savremene drame 2. Beograd, Hartefakt fond. Braszczyński O., 2014: Wstęp do myślenia o performatywnym czytaniu dramatu. W: A. Grabowski, J. Kopciński, red.: Dramat $w$ tekście - tekst $w$ dramacie. Warszawa, Wydawnictwo Instytutu Badań Literackich PAN, s. 49-60.

Cielesta A., Zwierzchowska D., 2011: Dramat serbski po 1995 roku. W: A. Cielesta, L. Małczak, D. Zwierzchowska, red.: Serbska ruletka. Dramat serbski po 1995 roku. T. 1. Katowice, Wydawnictwo Uniwersytetu Śląskiego.

Demirski P., 2015: Teatr dramatopisarzy. „Polish Theatre Journal”, nr 1, s. 1-6. Đerić Z., red., 2016: Nova srpska drama 2007-2015. Novi Sad, Sterijino pozorje. Dragović N., 2009: Dramaty Aleksandra Popovicia. Głos reżysera. „Południowosłowiańskie Zeszyty Naukowe. Język - Literatura - Kultura”, nr 6, s. 195199.

Đurić D., 2013: Politika i teatar: „Zoran Đinđic” Olivera Frljića i „Oni žive” Milana Markovića i Maje Pelević. „Poznańskie Studia Slawistyczne”, nr 5, s. 89-101.

Golka M., 2010: Imiona wielokulturowości. Warszawa, Warszawskie Wydawnictwo Literackie Muza.

Grabowski A., Kopciński J., 2014: Dramat - przedmiot do odnalezienia (słowo wstępne). W: A. Grabowski, J. Kopciński, red.: Dramat w tekście - tekst w dramacie. Warszawa, Wydawnictwo Instytutu Badań Literackich PAN, s. 7-26.

Injac G., red., 2011: Postpolityczność. Antologia nowego dramatu serbskiego. Kraków, Panga Pank.

Jezerkić V., Jovanov S., red., 2006: Predsmrtna mladost: antologija najnovije srpske drame (1995-2005). I deo. Novi Sad, Sterijino pozorje.

Jezerkić V., Jovanov S., red., 2007: Istorija i iluzija: antologija najnovije srpske drame (1995-2005). II deo. Novi Sad, Sterijino pozorje.

Kielawski R., Samanipour A., 2015: Różne wymiary udomowienia w tłumaczeniu dramatu - „Love and Information Caryl Churchill” w przekładzie Pawła Demirskiego. W: A. Filipek, M. Osiecka, M. Gwóźdź, K. Małajowicz, red.: Wkład w przekład 3. Kraków, Korporacja Ha!art, s. 159-176.

Krnajski K., Jovanov S., red., 2015: Antologija drama dobitnika Mihizove nagrade. Kraljevo, Biblioteka „Pozorja” / Kulturni centar „Ribnica”.

Lazin M., 2007: Nova drama - nova gluma? W: S. Anđelković, B. Senker, red.: Govor drame. Govor glume. Zagreb, Disput, s. 103-117.

Lehmann H.-T., 2004: Teatr postdramatyczny. D. Sajewska, M. Sugiera, tłum. Kraków, Księgarnia Akademicka. 
Majdzik K., 2013: Literatura chorwacka i jej polscy ambasadorzy. Uwagi do bibliografii przekładów literatury chorwackiej w Polsce w latach 2007-2013. „Przekłady Literatur Słowiańskich”, t. 5, cz. 2, s. 43-60.

Małczak L., 2014: Przekłady literatury serbskiej w Polsce w latach 2007-2013. „Przekłady Literatur Słowiańskich”, t. 5, cz. 2, s. 141-149.

Milivojević Mađarev M., 2015: Šta se štampa, a šta izvodi od savremene srpske dramske književnosti (2003-2015). „Scena”, nr 4, s. 126-135.

Milivojević Mađarev M., 2016: Novo iščitivanje prvonagrađenih drama. W: Z. Đerić, red.: Nova srpska drama 2007-2015. Novi Sad, Sterijino pozorje, s. 353-366.

Morawski W., 1998: Zmiana instytucjonalna. Społeczeństwo, gospodarka, polityka. Warszawa, Wydawnictwo Naukowe PWN.

Nelević N., 2012: Siroti dramski tekst: novi pristupi pozorištu. „Gest”, nr 3, s. 69-72.

Nikolić D., 2015: Prepoznavanje novih tokova u srpskoj dramaturgii. „Scena”, nr $1 / 2$, s. $52-54$.

Niziołek J., 2014: Cztery razy „Don Juan”: polskie dwudziestowieczne przekłady Moliera. Kraków, Wydawnictwo Naukowe Uniwersytetu Pedagogicznego.

Pucek Z., 2005: Arjun Appadurai i antropologia bez granic. W: A. Appadurai: Nowoczesność bez granic. Kulturowe wymiary globalizacji. Z. Pucek, tłum. Kraków, Universitas, s. XII-XIV.

Ratajczakowa D., 2006: W krysztale i w płomieniu. Studia i szkice o dramacie i teatrze. Cz. 2. Wrocław, Wydawnictwo Uniwersytetu Wrocławskiego, s. 9-17. Romčević N., 2011: Teatr w Serbii w latach 1990-2010. L. Małczak, tłum. W: Serbska ruletka. Dramat serbski po 1995 roku. T. 1. Katowice, Wydawnictwo Uniwersytetu Śląskiego, s. 43-49.

Saganiak M., 2014: Lektura dramatu - czyli o możliwej wyższości czytelnika dramatu nad widzem spektaklu. W: A. Grabowski, J. Kopciński, red.: Dramat $w$ tekście - tekst $w$ dramacie. Warszawa, Wydawnictwo Instytutu Badań Literackich PAN, s. 27-48.

Sokulska A., 2014: Dramat kobiecy, kobieta $w$ dramacie. Wokół dramaturgii Mai Pelević. „Studenckie Zeszyty Naukowe Instytutu Filologii Słowiańskiej UJ”, numer specjalny, s. 5-51.

Stefanović M., Kaliterna T., red., 2011: Radnici umiru pevajući. Drame. Beograd, Hartefakt fond.

Tokarz B., 2006: Model przekładu a stereotyp płci. W: P. Fast, red.: Płeć w przekładzie. Katowice, Wydawnictwo Śląsk-Częstochowa, Wydawnictwo Wyższej Szkoły Lingwistycznej.

Vujanović A., 2004: Drama bez scene: hrapave konceptualizacije dramske produkcije novih autora u Srbiji. „Scena”, nr 4. Dostępne w Internecie: http:// www.pozorje.org.rs/stari-sajt/scena/scena404/19.htm [dostęp: 13.09.2019]. 
Vujanović A., 2010: Nova - „postpolitička” - drama. W: M. Šuvaković, red.: Istorija umetnosti u Srbiji XX vek. Beograd, Orion Art, s. 771-778.

\section{Gabriela Abrasowicz}

\section{Granice nove srpske drame - fluidne i stalno redefinisane Lokalna perspektiva i recepcija u Poljskoj}

REZIME | Na prelazu između milenijuma srpska drama postala je cenjena i prepoznata u postjugoslovenskom regionu i Evropi. Poslednjih godina proces globalizacije je sve snažniji, infrastruktura i sistem promocije su se poboljšali, što omogućava prekoračivanje materijalnih i simboličkih granica (transformacija umetničkog izražaja, kulturna mobilnost, koprodukcije, prevodi). Treba napomenuti da je početak 20. veka (naročito njegova druga decenija) doneo ozbiljnije interesovanje u zemlji i inostranstvu za dramsku i scensku produkciju. Objavljene su antologije savremene srpske drame: Nova srpska drama, Biseri iz upravničkih fioka, koje popularišu dramske tekstove i uvode ih u književni i pozorišni krug, poboljšavajući tako njihovu recepciju. Na taj se način širi svest o ovom stvaralaštvu i povećavaju se šanse autora i autorki da kroz scenske produkcije ili scenska čitanja uđu u glavne umetničke tokove. Poljski prevodioci takođe postepeno postaju sve više zainteresovani za dramatičare iz Srbije.

Status drame može biti problematičan jer se ona nalazi između književnosti i pozorišta. Njena heterogena priroda zahteva pravilan način realizacije. Pozorišni komad treba da se vidi, čuje i govori, a ne da se samo tiho čita. Ipak, postoji scensko čitanje kao pojednostavljeni oblik pozorišta gde glumci performativno čitaju scenario pred publikom. Ovo podrazumeva istraživanje pozorišta kad produkcija nije u potpunosti ostvarena i kad je naglasak stavljen na slušanje teksta, ne na gledanje izvođenja.

KLJUČNE REČI | srpska drama i pozorište, prevod dramskog teksta, performativno/scensko čitanje, sistem promocije, srpska drama u Poljskoj

\section{Gabriela Abrasowicz}

\section{The Borders of the New Serbian Drama - Fluid and Constantly Redefined: The Local Perspective and Reception in Poland}

SUMMARY | Since the turn of the millennium, Serbian drama has been increasingly valued and recognized in the post-Yugoslav region and in Europe. In recent years, the process of globalization has become progressively stronger, with an improved infrastructure for promotion that has made possible the crossing of material and symbolic boundaries. This in turn has led to transformations in artistic expression, as well as increasing opportunities for mobility, co-productions, and translations. It should be noted that recent years have brought the harbingers of more serious interest in playwriting and stage productions in both literary and theatre communities. Anthologies of contemporary Serbian drama have been published, such as New Serbian Drama and Pearls from Directors' Drawers, which popularise dramatic texts and introduce them into literary and theatrical circulation, 
thus enhancing their reception and public awareness while increasing their chances of joining the literary mainstream through stage productions or stage readings. Polish translators are also gradually becoming increasingly more interested in Serbian playwrights.

The status of drama can be problematic because it is situated between literature and theatre. Its heterogeneous nature requires a proper implementation method. A play is meant to be seen, heard, and spoken, rather than read silently. A staged reading is a simplified form of theatre that is realized by actors with scripts in hand before an audience. Performative reading is a means of exploring a piece of theatre without being a fully-realized production, where the emphasis is on hearing the text instead of seeing it.

KEYWORDS | Serbian drama and theatre, translation of the dramatic text, performative/stage readings, promotion system, Serbian drama in Poland

GABRIELA ABRASOWICZ | dr nauk humanistycznych w zakresie literaturoznawstwa, slawistka. Na Uniwersytecie Śląskim w Katowicach realizuje projekt badawczy (Trans)pozycje idei $w$ chorwackim i serbskim dramatopisarstwie oraz teatrze (1990-2020). Perspektywa transkulturowa finansowany ze środków Narodowego Centrum Nauki. Przedmiotem jej badań naukowych jest współczesny dramat i teatr postjugosłowiański. Autorka książki Dramat ciała. Ciało $w$ dramacie. Twórczość serbskich i chorwackich dramatopisarek $w$ latach 19902010 (Wrocław 2016) oraz artykułów poświęconych analizie dramatopisarstwa i produkcji teatralnej w krajach byłej Jugosławii z perspektywy antropologii ciała, gender studies i transkulturowości. Współredaktorka (z Leszkiem Małczakiem) antologii (Nie tylko) fragmenty. Wybór nowych dramatów chorwackich (Katowice 2019). Zajmuje się przekładem dramatopisarstwa chorwackiego, serbskiego i bośniackiego na język polski. Współpracuje z Chorwackim Centrum ITI, festiwalem Sterijino pozorje oraz Międzynarodowym Festiwalem Teatralnym Demoludy w Olsztynie. 